\title{
Aplikasi Progressive Muscle Relaxation Sebagai Upaya Reduksi Nyeri Dan Kecemasan
}

\author{
Jum Natosba ${ }^{1}$, Sigit Purwanto ${ }^{2}$, Jaji $^{3}$, Firnaliza Rizona ${ }^{4}$ \\ Program Studi Ilmu Keperawatan Fakultas Kedokteran Universitas Sriwijaya $a^{1,2,3,4}$ \\ Corresponding Email: jumnatosba_bayd@yahoo.co.id
}

\begin{abstract}
ABSTRAK
Nyeri dan kecemasan merupakan dua gejala yang paling sering dirasakan oleh penderita kanker. Pengobatan terhadap keluhan penderita kanker ini dapat ilakukan melalui terapi komplementer sebagai pelengkap. Salah satu teknik relaksasi yaitu PMR yang dilakukan dengan cara menegangkan otot secara sementara, kemudian kembali diregangkan dimulai dari kepala sampai kaki secara bertahap. Tujuan kegiatan pengabdian kepada masayarakat ini adalah untuk meningkatkan kemampuan adaptasi pasien kanker terhadap nyeri dan kecemasan yang dirasakannya. Kegiatan dilakukan selama satu hari dengan latihan bertempat di ruangan serbaguna di wisma RSMH Palembang. Sebelumnya pada awal kegiatan dilakukan pengukuran terkait nyeri dan kecemasan. Selanjutnya akhir sesi latihan dilakukan pengukuran lagi untuk nyeri dan kecemasan. Kegiatan pengabdian masyarakat dilaksanakan di wisma RSMH Palembang, 12 orang pasien kanker yang menghadiri kegiatan tersebut. Selama penyuluhan peserta penyuluhan antusias dalam mendengarkan, melaksanakan senam, mengulangi gerakan senam dan berdiskusi dengan narasumber. Terdapat penurunan nyeri dan kecemasan sebelum dan sesuedah dilakukan PMR. PMR bekerja meningkatkan kerja saraf parasimpatis dan menurunkan stimulasi sistem saraf simpatis serta hipotalamus sehingga pengaruh stres fisik terhadap keduanya menjadi minimal. Berdasarkan pemahaman inilah latihan PMR mampu mengurangi distress akibat gejala fisik.
\end{abstract}

Kata kunci: Nyeri, kecemasan, Progressive Muscle Relaxation

\begin{abstract}
Pain and anxiety are two of the most common symptoms of cancer sufferers. Treatment of the sufferer of these cancer complaints can be done through complementary therapy as a complement. One of the relaxation techniques of PMR is done in a temporary way of muscle strain, then re-stretched from head to toe gradually. The purpose of the devotion to the community is to improve the ability of the cancer patient adaptation to the pain and anxiety he felt. The activity is done for one day with an exercise in the multipurpose room in Palembang RSMH guesthouse. Earlier activities were carried out measurements of pain and anxiety. Furthermore the end of the training session is carried out more measurements for pain and anxiety. Public service activities were held at the RSMH guesthouse in Palembang, 12 cancer patients attending the event. During counseling participants enthusiastic about listening, conducting gymnastics, repeating the movement of gymnastics and discussing with speakers. There is a decrease in pain and anxiety before and according to PMR. PMR works increase the work of the parasympathetic nerve and lowers the stimulation of the sympathetic nervous system as well as the hypothalamus so that the
\end{abstract}


influence of physical stress on both becomes minimal. Based on this understanding, PMR exercises are able to reduce distress due to physical symptoms.

Keywords: pain, anxiety, Progressive Muscle Relaxation

\section{PENDAHULUAN}

Kanker merupakan pertumbuhan sel dalam tubuh yang abnormal dan tidak terkontrol sehingga dapat menjadi suatu keganasan yang berakibat fatal bagi kehidupan seseorang (Rasjidi, 2009). Sel-sel kanker membentuk suatu massa dari jaringan ganas yang menyusup ke jaringan di dekatnya dan dapat menyebar ke seluruh tubuh. Penyakit ini sangat kompleks dengan berbagai manifestasi tergantung pada sistem tubuh yang dipengaruhi dan jenis sel kanker yang terlibat (Tobing, 2012). Sel kanker dapat tumbuh dengan cepat dan menyebabkan kematian apabila tidak segera diberikan perawatan (LeMone, \& Burke, 2008).

Nyeri dan kecemasan merupakan dua gejala pada penderita kanker yang memiliki hubungan saling berkaitan. Nyeri merupakan salah satu gejala kanker yang paling sering dan merupakan beban berat bagi pasien selama sakit (Shute, 2013). Kecemasan pada penderita kanker muncul akibat perasaan yang tidak pasti akan prognosa penyakit, keluhan nyeri yang dirasakan, pemeriksaan diagnostik yang dilakukan, dan pengobatan yang dijalani terhadap pemulihan kondisi terutama pada pasien stadium lanjut.

Pengobatan terhadap keluhan penderita kanker tidak hanya dapat dilakukan melalui terapi farmakologi, namun terdapat terapi komplementer sebagai pelengkap. Salah satu terapi komplementer yang dapat diberikan kepada pasien kanker serviks ialah relaksasi yang dilakukan untuk membantu penderita berinteraksi dengan lingkungannya (Varvogli \& Darviri, 2011). Salah satu teknik relaksasi yaitu PMR yang dilakukan dengan cara menegangkan otot secara sementara, kemudian kembali diregangkan dimulai dari kepala sampai kaki secara bertahap (Casey, \& Benson, 2012). PMR bertujuan untuk membedakan perasaan yang dialami pada saat kelompok otot dilemaskan dan dalam kondisi tegang. Penderita dapat merasakan hilangnya ketegangan sebagai salah satu respon nyeri dan kecemasan di mana terapi PMR dapat merangsang pengeluaran endorphin dan merangsang signal otak yang menyebabkan otot relaks serta dapat meningkatkan aliran darah ke otak (Tobing, 2012).. PMR merupakan salah satu dari teknik relaksasi yang paling mudah dilakukan, memiliki gerakan sederhana, telah digunakan secara luas, dan dapat meningkatkan kemandirian pasien dalam mengatasi masalah kesehatan secara non farmakologik(Maryani, 2009; Syarif \& Putra, 2014). Teknik relaksasi ini dapat menimbulkan keselarasan tubuh dan pikiran yang diyakini memfasilitasi penyembuhan fisik dan psikologis (LeMone, \& Burke, 
2008). Tujuan kegiatan pengabdian kepada masayarakat ini adalah untuk meningkatkan kemampuan adaptasi pasien kanker serviks terhadap nyeri dan kecemasan yang dirasakannya.

\section{METODE}

Kegiatan dilakukan selama satu hari berturut-turut dengan latihan bertempat di ruangan serbaguna di wisma RSMH Palembang. Pemilihan wisma RSMH Palembang untuk memenuhi kebutuhan latihan Progressive Muscle Relaxational akan lingkungan yang tenang, posisi yang nyaman, dan sikap yang baik dibandingkan ruang rawat rumah sakit. Lingkungan yang tenang diperlukan sehingga pasien dapat berkonsentrasi pada relaksasi otot termasuk membantasi interupsi/gangguan, suara, dan pencahayaan. Posisi yang nyaman memberikan dukungan bagi tubuh atau berbaring di tempat tidur pada posisi yang nyaman. Pelaksanaan PMR untuk hasil yang maksimal dianjurkan dilakukan secara rutin selama 25-30 menit sebanyak 2 kali sehari. Sebelumnya pada awal kegiatan dilakukan pengukuran terkait nyeri dan kecemasan. Selanjutnya akhir sesi latihan dilakukan pengukuran lagi untuk nyeri dan kecemasan. Evaluasi dilakukan berdasarkan tahapan kegiatan pengabdian masyarakat dan dilakukan pada setiap khalayak sasaran. Dijelaskan pada bagan dibawah ini:

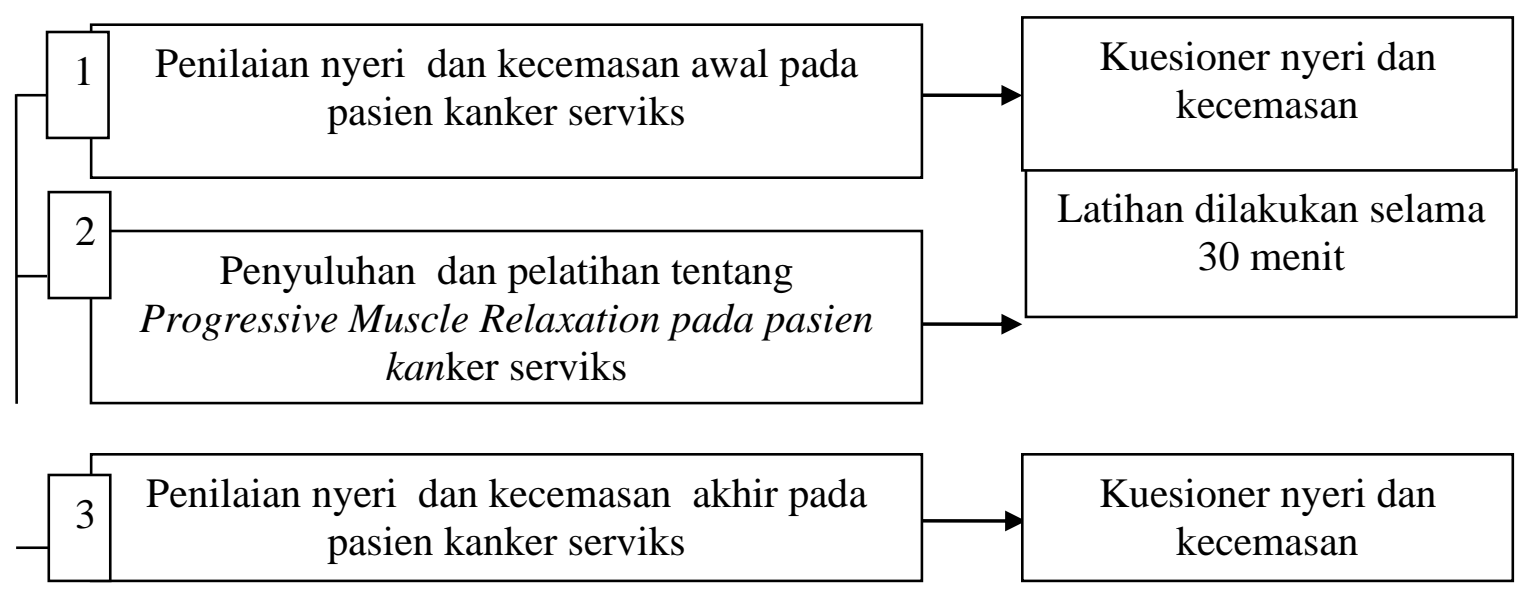

\section{PELAKSANAAN DAN PEMBAHASAN}

\section{Survei pasien}

Kegiatan pengabdian masyarakat dilaksanakan di wisma RSMH Palembang dengan fasilitator kepala rumah singgah yang juga bekerja di bagian K3 RSMH Palembang. Tahap awal kegiatan dengan mencari pasien kanker yang menginap di wisma RSMH Palembang. Kegiatan ini dibantu oleh mahasiswa program studi ilmu keperawatan dan alumni. Pada tahap ini sudah mulai dilakukan pengkajian minat untuk melakukan latihan Progressive Muscle 
Relaxation. Hasilnya adalah sebagian besar berminat untuk melakukan latihan $P M R$ tetapi beberapa pasien kanker berhalangan hadir karena mengurus surat administrasi untuk kemoterapi keesokan harinya. Tahap ini diperoleh 20 pasien kanker yang mau mengikuti kegiatan penyuluhan dari total 40 kamar yang disewakan di wisma RSMH Palembang. Tidak terlalu banyak peserta dikarenakan penghuni wisma tidak hanya pasien kanker melainkan ada orang yang tidak sakit dan bukan pasien RSMH Palembang, menunggu istri melahirkan, menunggu anaknya dirawat di NICU, mengantar anaknya yang masih bayi berobat karena menderita kanker, sehingga tidak sesuai dengan kreteria peserta pada pelatihan ini.

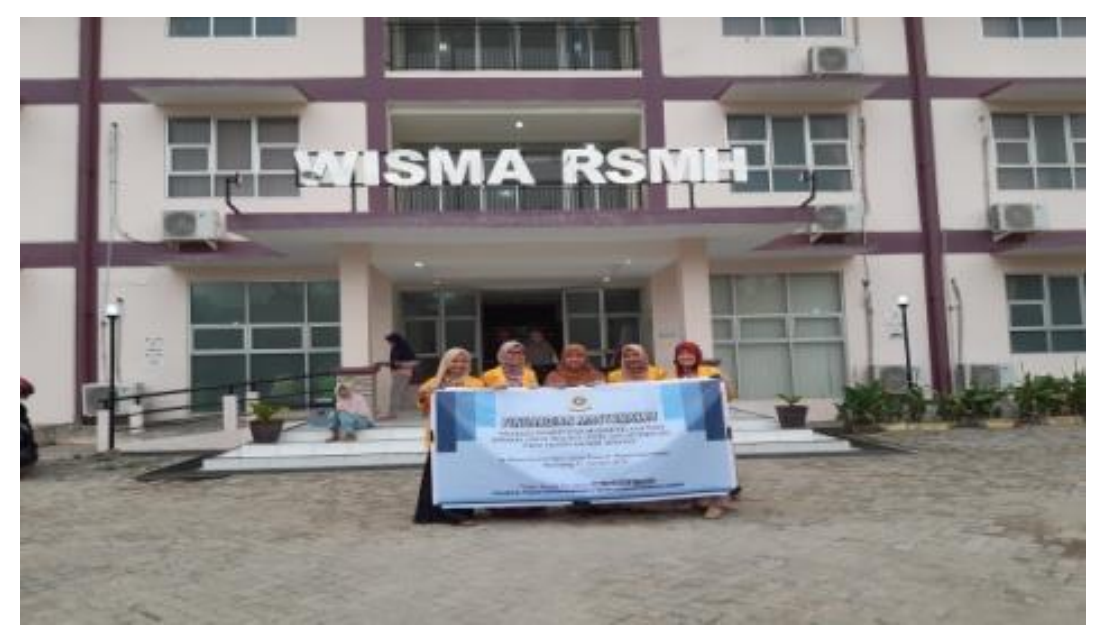

Gambar 1. Tempat pelaksanaan penyuluhan

\section{Penyuluhan kesehatan}

Tanggal 31 Oktober 2019 merupakan pelaksanaan penyuluhan dan pelatihan tentang $P M R$ pada pasien kanker hanya diperoleh 12 orang pasien kanker yang menghadiri kegiatan tersebut. Kegiatan penyuluhan dilakukan oleh ketua pelaksana dibantu oleh anggota dan 4 orang alumni. Materi yang diberikan terkait latihan PMR Selama penyuluhan peserta penyuluhan antusias dalam mendengarkan, melaksanakan senam, mengulangi gerakan senam dan berdiskusi dengan narasumber. Hasil evaluasi menunjukan $75 \%$ peserta penyuluhan mampu menjelaskan kembali definisi, manfaat, kondisi yang mendukung untuk pelaksanaan latihan PMR.

Suasana penyuluhan dan pelatihan senam berlangsung kondusif kondusif. Penyuluhan kesehatan bertujuan untuk meningkatkan pengetahuan dan kesadaran peserta untuk melakukan pelatihan PMR. Harapan yang ingin dicapai adalah peserta dapat menerapkan pengetahuan yang dimiliki dalam perilaku hidup sehat, diantaranya dengan kesadaran melakukan latihan PMR. Penelitian menunjukan bahwa dengan dilakukan intervensi akan menambah tingkat pengetahuan seseorang terhadap suatu objek tertentu (Saraswati, 2012). 
Pengetahuan seseorang tidak akan bisa bertambah dan berkembang tanpa adanya penambahan informasi melalui media apapun.

Pemberian pendidikan kesehatan memberi dampak terhadap tingkat pengetahuan dan berpengaruh dalam pengambilan keputusan dalam melakukan latihan PMR. Penelitian lain membuktikan bahwa pemberian pendidikan kesehatan yang teratur dengan materi yang sederhana, metode yang tepat, pemberi materi yang adekuat dan waktu yang sesuai dengan waktu responden akan meningkatkan pengetahuan secara bermakna terhadap sikap, dan perilaku (Purnamasari, 2012). Pemberian pengetahuan yang disampaikan melalui pendidikan kesehatan akan membawa dampak tejadinya peningkatan pengetahuan dari yang tidak tahu menjadi tahu, sehingga dengan dilakukannya pendidikan kesehatan akan mudah diterima.

\section{Pelatihan Progressive Muscle Relaxation}

Kegiatan ini juga dilakukan penilaian sebelum dan setelah pelatihan terkait nyeri dan kecemasan. Hasil penilaian tersebut dijelaskan pada tabel 1 dan 2 Pelaksanaan latihan PMR dapat menstimulasi tubuh dalam menghasilkan hormon endorphin yang berfungsi sebagai obat penenang alami yang diproduksi otak sehingga menimbulkan perasaan relaks (Ramania, Natosba \& Adhisty, 2017).
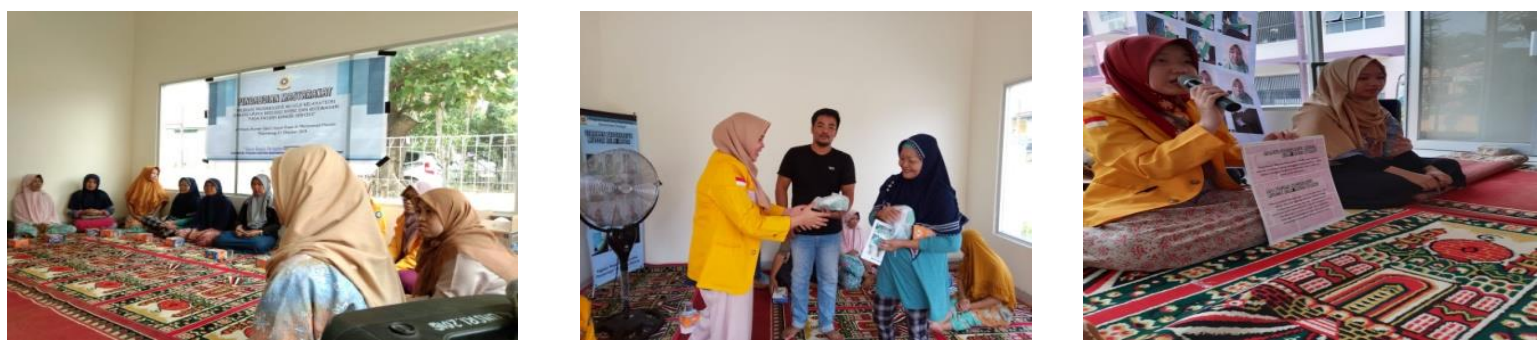

Gambar 2. Proses penyuluhan

Tabel 1. Gambaran karakteristik responden

\begin{tabular}{|c|c|c|}
\hline Variabel & $\begin{array}{c}\text { Frekuensi } \\
(\mathrm{n}=12)\end{array}$ & $\begin{array}{c}\text { Persentase } \\
(\%)\end{array}$ \\
\hline \multicolumn{3}{|l|}{ Jenis kelamin } \\
\hline Laki-laki & 5 & 41,7 \\
\hline Perempuan & 7 & 58,3 \\
\hline \multicolumn{3}{|l|}{ Umur } \\
\hline Berisiko (>35 tahun) & 9 & 75 \\
\hline Tidak berisiko ( $\leq 35$ tahun) & 3 & 25 \\
\hline \multicolumn{3}{|l|}{ Pendidikan } \\
\hline Pendidikan menengah dan tinggi & 6 & 50 \\
\hline Pendidikan rendah & 6 & 50 \\
\hline \multicolumn{3}{|l|}{ Status pekerjaan } \\
\hline Tidak bekerja & 8 & 66,7 \\
\hline
\end{tabular}




\begin{tabular}{lcc}
\hline \multicolumn{1}{c}{ Variabel } & $\begin{array}{c}\text { Frekuensi } \\
(\mathbf{n = 1 2})\end{array}$ & $\begin{array}{c}\text { Persentase } \\
(\mathbf{\%})\end{array}$ \\
\hline Jenis kelamin & & 41,7 \\
\hline Laki-laki & 5 & 58,3 \\
\hline Perempuan & 7 & 33,3 \\
\hline Bekerja & 4 & \\
Pendapatan & & 58,3 \\
tinggi & 7 & 41,7 \\
Rendah & 5 & \\
Lama menderita kanker & & 75 \\
$>1$ tahun & & 25 \\
$\leq 1$ tahun & 9 & \\
Status Pernikahan & 3 & 58,3 \\
Menikah dan Tinggal Bersama & & 25 \\
Menikah dan Tidak Tinggal Bersama & & \\
Ditinggal Pasangan (Meninggal) & 7 & \\
Pengobatan Yang Dijalani & 3 & 41,7 \\
Kemoterapi & 2 & 25 \\
Radioterapi & & \\
Kemoterapi dan Radioterapi & 5 &
\end{tabular}

Tabel 2. Distribusi nyeri dan kecemasan Sebelum dan setelah penyuluhan dan pelatihan tentang $P M R$

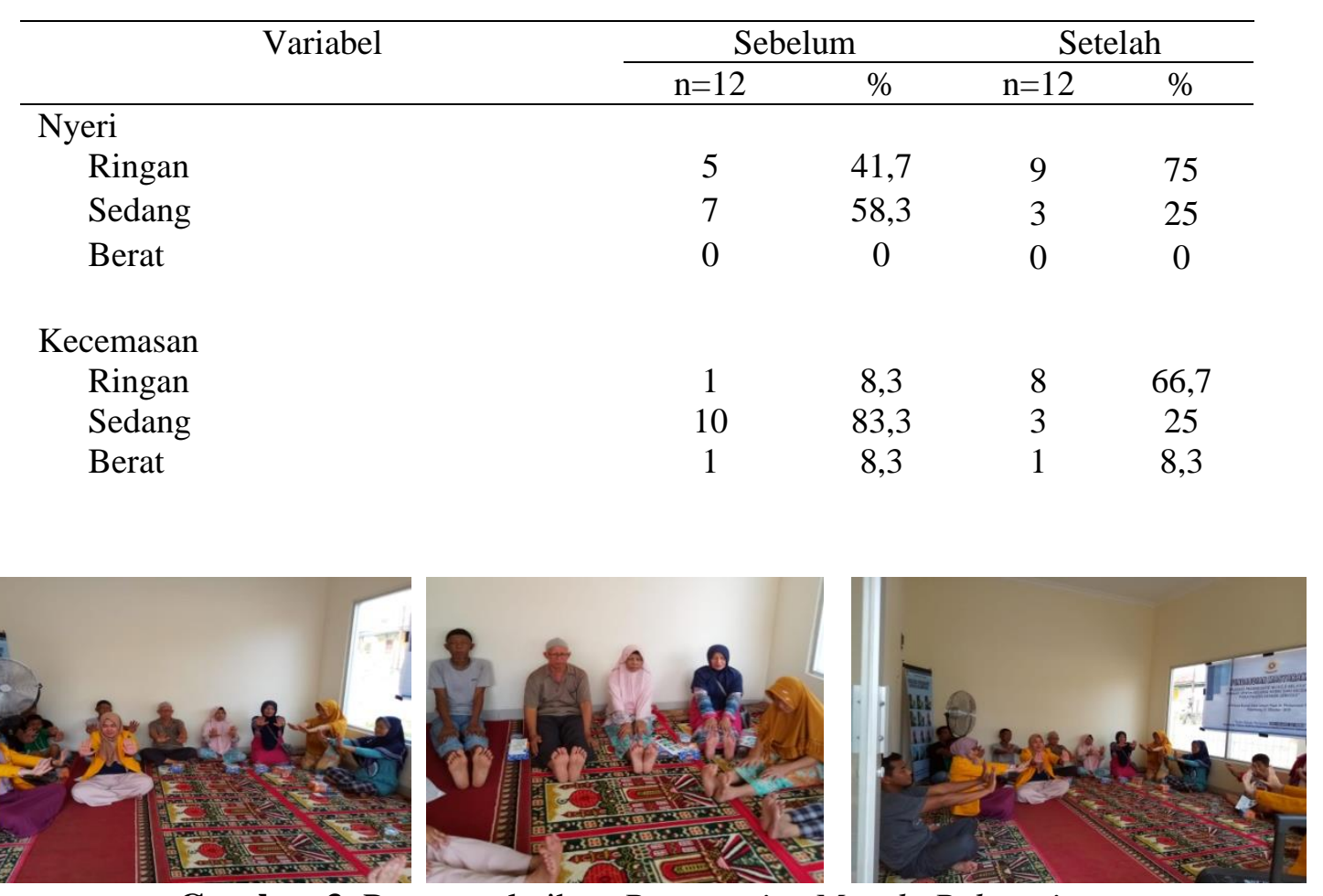

Gambar 3. Proses pelatihan Progressive Muscle Relaxation 
Kadar endorphin yang dihasilkan karena aktivitas latihan meningkat 4-5 kali sehingga semakin banyak melakukan latihan dapat memicu pengeluaran endorphin lebih banyak, kemudian hormon tersebut digunakan oleh reseptor di dalam hipotalamus dan sistem limbik untuk mengatur emosi (Simamora, Sinaga, \& Olivia, 2014). Menurut penelitian Mashudi (2012) bahwa PMR akan membantu mengurangi ketegangan otot dan stres. PMR dapat memperlancar aliran darah dan menurunkan ketegangan otot yang berhubungan dengan mengecilnya serabut otot sehingga memberikan efek relaksasi (Setyoadi \& Kushariyadi, 2011; Soewondo, 2012).

Latihan PMR terdiri dari latihan nafas dalam, serangkaian seri kontraksi serta relaksasi otot tertentu, dan distraksi. Proses distraksi pada latihan PMR menjadi penyebab perubahan intensitas nyeri yang dirasakan oleh peserta pelatihan. Selama latihan PMR distraksi mengarahkan peserta harus berfokus pada setiap gerakan yang dilakukan sehingga dapat mengalihkan perhatian responden dan menurunkan persepsi nyeri yang dirasakan. Rasa nyaman mulai dirasakan pada gerakan ke-12 dan 13 dikarenakan pusat nyeri yang dirasakan berada pada bagian adomen (perut) sehingga peneliti menganjurkan untuk memperbanyak melakukan gerakan di daerah tersebut (Ramania, Natosba \& Adhisty, 2017).

Menurut Haryati (2015) latihan PMR bekerja meningkatkan kerja saraf parasimpatis dan menurunkan stimulasi sistem saraf simpatis serta hipotalamus sehingga pengaruh stres fisik terhadap keduanya menjadi minimal. Berdasarkan pemahaman inilah latihan PMR mampu mengurangi distress akibat gejala fisik yang ditandai dengan denyut jantung menurunkan, laju pernafasan menjadi lebih lambat, aliran darah ke otot dan saluran pencernaan meningkat (Ramadhan \& Putra, 2008). Penyampaian stimulus ke sistem saraf pusat tersebut menyebabkan terjadinya pelepasan endorphin yang menyebabkan ketegangan otot menjadi berkurang sehingga membuat tubuh menjadi relaks. PMR telah membantu pasien kanker serviks untuk meningkatkan relaksasi terhadap berbagai gejala dan keluhan yang dirasakan sehingga pasien lebih toleran terhadap berbagai aktivitas sehari-hari (Ramania, Natosba \& Adhisty, 2017).

PMR juga terbukti dapat mengurangi kecemasan. Menurut Jacobson (1970) dikutip Haryati (2015) kecemasan disebabkan oleh ketegangan otot dan akan berkurang dengan relaksasi otot. $P M R$ dapat memberikan manfaat ganda yaitu menimbulkan adaptasi individu yang lebih positif dalam waktu yang singkat dan penurunan kecemasan yang tidak bergantung pada proses netralisir stressor (Ramania, Natosba \& Adhisty, 2017). Tingkat kecemasan dan intensitas nyeri mempunyai korelasi yang signifikan, nyeri dapat ditingkatkan 
oleh kecemasan bila perhatian difokuskan pada sensasi-sensasi yang biasanya tidak dianggap nyeri (seperti parestesi, rasa gatal dan kadang-kadang bahkan denyutan jantung atau gerakan usus) (Melzack dan Wall, 2006).

Blindes., et al (2008) menyatakan bahwa nyeri selalu diikuti gangguan emosi seperti cemas, depresi dan iritasi. Hasil penelitian Ramania, Natosba \& Adhisty (2017) menyatakan bahwa skor kecemasan mengalami penurunan bersamaan dengan penurunan terhadap skala nyeri. Hasil penelitian menyatakan bahwa dari 42,3\% responden yang mengalami kecemasan berat, sebanyak 30,8\% merasakan intensitas nyeri berat (Butar-Butar, Yustina, dan Harahap, 2015). Individu yang cemas dan tegang akan membuka gerbang sehingga akan meningkatkan rangsang nyeri, yang dapat dilihat dari teori gate control yaitu jika modulasi input melewati input nosisepsi, gerbang kemudian diblok dan transmisi nosisepsi berhenti atau dihalangi di substansia gelatinosa tanduk dorsal dari korda spinalis (Kaplan, Sadock, \& Grebb, 2010).

\section{SIMPULAN}

Tanggal 31 Oktober 2019 merupakan pelaksanaan penyuluhan dan pelatihan tentang PMR pada pasien kanker hanya diperoleh 12 orang pasien kanker yang menghadiri kegiatan tersebut. Materi yang diberikan terkait latihan PMR. Selama penyuluhan peserta penyuluhan antusias dalam mendengarkan, melaksanakan senam, mengulangi gerakan senam dan berdiskusi dengan narasumber. Hasil evaluasi menunjukan $75 \%$ peserta penyuluhan mampu menjelaskan kembali definisi, manfaat, kondisi yang mendukung untuk pelaksanaan latihan PMR. PMR juga terbukti dapat mengurangi nyeri dan kecemasan. PMR dapat memberikan manfaat ganda yaitu menimbulkan adaptasi individu yang lebih positif dalam waktu yang singkat dan penurunan kecemasan yang tidak bergantung pada proses netralisir stressor

\section{DAFTAR PUSTAKA}

Blindes, LM., Hill, OW., Merskey H. (2008). Abdominal Pain and the Emotional. Journal Pain 5:179-191.

Butar-Butar, D., Yustina, I., Harahap, I.A. (2015). Hubungan Karakteristik Nyeri dengan

Kecemasan pada Pasien Kanker Payudara yang Menjalani Kemoterapi di RSUD Dr. Pirngadi Medan. Idea Nursing Journal 1(1): 51-60.

Casey, A \& Benson, H.(2012). Panduan Harvard Medical School:Menurunkan Tekanan

Darah, Jakarta:PT Bhuana Ilmu Populer. 
Haryati, Sitorus, Ratna. (2015). Pengaruh Latihan Progressive Muscle Relaxation Terhadap Status Fungsional dalam Konteks Asuhan Keperawatan Pasien Kanker dengan Kemoterapi di RS.dr.Wahidin Sudirohusodo Makassar. Jurnal Medula 2(2):167-177.

Kaplan, H.I, Sadock, B.J,\& Grebb J.A. (2010). Sinopsis Psikiatri Jilid 2. Jakarta: Binarupa Aksara.

LeMone, P., \& Burke,K. (2008). Medical Surgical Nursing:Critical Thinking in Client Care $4^{\text {th }} E d$. New Jersey:Pearson Prentice Hall.

Maryani,A. (2009). Pengaruh Progressive Muscle Relaxation Terhadap Kecemasan dan Mual Muntah Setelah Kemoterapi pada Pasien Kanker Payudara di RS.dr.Hasan Sadikin Bandung. Tesis dipublikasikan. Jakarta:Program Pascasarjana Fakultas Ilmu Keperawatan Universitas Indonesia.

Mashudi. (2011). Pengaruh Progressive Muscle Relaxation Terhadap Kadar GLukosa Darah Pasien Diabates Mellitus Tipe 2 di Rumah Sakit Umum Daerah Raden Mattaher Jambi. Tesis dipublikasikan. Jakarta:Universitas Indonesia.

Melzack, R.., Wall, P.D. (2006). Pain Mechanisms : A New Theory. Science New Series Journal 150(36): 20-26.

NANDA International. (2011). Diagnosis Keperawatan:Definisi dan Klasifikasi 2012-2014. Jakarta: EGC.

Ramadhani, N., Putra, A.A. (2008). Pengembangan Multimedia Relaksasi.(Online).Diakses di http://staf.ugm.ac.id/relaksasi_otot.pdf pada 30 Mei 2018.

Ramania, E.N, Natosba, J \& Adhisty, K (2017). Pengaruh Progressive Muscle Relaxation Terhadap Nyeri Dan Kecemasan Pasien Kanker Serviks. Skripsi. PSIK FK UNSRI. Tidak dipublikasikan

Rasjidi, 2010. Epidemiologi Kanker pada Wanita. Jakarta: Agung Seto.

Rasjidi, I. (2009). Deteksi dan Pencegahan Kanker pada Wanita. Jakarta: Agung Seto.

Setyoadi \& Kushariyadi. (2011). Terapi Modalitas Keperawatan pada Klien Psikogeriatrik. Jakarta:EGC.

Shute, C. (2013). The Challenges of Cancer Pain Assessment and Management. Ulster Medical Journal 82(1):40-42.

Simamora, L.L., Sinaga, F., Olivia, C. (2014). Pengaruh Relaksasi Otot Progresif Terhadap Nyeri Menstruasi pada Remaja di Asrama Putri STIKes Santo Borromeus. Diakses di http://ejournal.stikesborromeus.ac.id/ pada 2 Juni 2018.

Soewondo, S. (2012). Stress, Manajemen Stress, dan Relaksasi Progresif. Jakarta: LPSP3 UI. 
Syarif, Hilman, \& Putra, Ardia. (2014). Pengaruh Progressive Muscle Relaxation Terhadap Penurunan Kecemasan pada Pasien Kanker yang Menjalani Kemoterapi : A Randomized Clinical Trial. Idea Nursing Journal 5(3):1-8.

Tobing, Duma Lumban. (2012). Pengaruh Progressive Muscle Relaxation Terhadap Perubahan Ansietas, Depresi, Kemampuan Relaksasi, dan Kemampuan Memaknai Hidup Klien Kanker di RS.Dharmais Jakarta. Tesis dipublikasikan. Jakarta: Pascasarjana Fakultas Ilmu Keperawatan Kekhususan Keperawatan Jiwa Universitas Indonesia.

Varvogli, L. \& Darviri,C. (2011). Stress Management Techniques:Evidence-Based Procedures that Reduce Stress and Promote Health. Health Science Journal 5(2):74-89 E-ISSN:1791-809X. 